\title{
The secret of rendering signs effective: the import of C. S. Peirce's semiotic rhetoric
}

\author{
Mats Bergman \\ Arcada University of Applied Sciences \\ Helsinki, Finland \\ bergmanm@arcada.fi
}

\begin{abstract}
In this article I trace the historical development of Peirce's semiotic rhetoric from its early appearance as a sub-discipline of symbolistic to its mature incarnation as one of the three main branches of the science of semiotic, and argue that this change in status is a symptom of Peirce's broadening semiotic interest. The article shows how the evolution of Peirce's theory of signs is linked to changes in his conception of logic. This modification is not merely a minor justification in his classification of the sciences; rather, it indicates a growing understanding of the interconnection between the different semiotic sub-disciplines. The scope and character of the mature discipline of rhetoric is further discussed in terms of a possible clash between rhetorical and methodological emphases, and a conciliatory strategy is suggested. The article concludes with some reflections on the relevance of Peircean rhetoric for future work in Peirce studies and semiotics.
\end{abstract}

Almost 100 years have passed since Charles S. Peirce declared himself to be a "pioneer, or rather a backwoodsman, in the work of clearing and opening up [...] semiotic, that is, the doctrine of the essential nature and fundamental varieties of possible semiosis" (EP ${ }^{1}$ 2:413 [1907]). Few would today deny the historical significance of his labours. Still, in view of the remarkable growth of semiotics in the $20^{\text {th }}$ century, one may reasonably wonder whether Peirce's pioneering work is of any real relevance for contemporary semiotic inquiry. The elaborate trichotomies and hierarchies of Peircean sign theory can certainly appear dated and barren in a situation where semiotics is every so often dismissed as yesterday's intellectual fad and semioticians increasingly look for new approaches through which to reinvigorate their efforts.

Nonetheless, a return to Peirce might be just what semiotics needs. This claim may appear a bit misguided, if not outright imprudent; surely, the Peircean alternative must have been sufficiently tried and tested by now? I would argue that it has not. While the triadic model propounded by Peirce has made some gains in relation to the dyadic conception characteristic of de Saussure and his structualist followers, there are still several less obvious aspects of Peirce's project that have received only scant attention from semioticians. Indeed, certain promising leads concerning the varieties of semiotic inquiry have been all but ignored in the literature on Peircean semiotics.

\footnotetext{
${ }^{1}$ In accordance with the customs of Peirce scholarship, I will refer to collections of Peirce's texts using abbreviations in references given in the text. $C P x . y$ refers to The Collected Papers of Charles Sanders Peirce; $v$ indicates volume number, $p$, paragraph number. EP v:p refers to The Essential Peirce: Selected Philosophical Writings; $v$ indicates volume number, $p$, page number. $M S m$ refers to an original manuscript; $m$ indicates manuscript number. NEM v:p refers to The New Elements of Mathematics by Charles $S$. Peirce; $v$ indicates volume number, $p$, page number. SS $p$ refers to Semiotics and Significs: The Correspondence between Charles S. Peirce and Victoria Lady Welby; $p$ indicates page number. Wv:p refers to Writings of Charles S. Peirce: A Chronological Edition; $v$ indicates volume number, $p$, page number. Where known, the year of writing or publication will be given.
} 
Studies of Peirce's theory of signs have typically focused on the sub-disciplines he identified as grammar and critic, with comparatively little attention being paid to his third semiotic study, that is, to the field of inquiry he denoted as rhetoric or methodeutic. This emphasis is partly understandable, as Peirce's writings on explicitly rhetorical issues tend to be sparse and suggestive. Also, one should note that a considerable part of the work done by Peirce's followers (and other semioticians) falls quite naturally within the scope of rhetoric, although this is seldom acknowledged. On the other hand, the lack of an explicit consideration of the scientific status and impact of the rhetorical study - the liveliest branch of semiotic, according to Peirce - threatens to turn Peircean semiotic into a mere logico-grammatical exercise, a kind of glass-bead game for zealous intellectuals that is easily ignored by the rest of the world. Perhaps this explains why leading Peirce scholars such as Lucia Santaella Braga and James Jakób Liszka have turned their attention to the question of rhetoric in recent years. ${ }^{2}$ While it is too soon to speak of a rhetorical turn in Peirce studies, it is nonetheless highly probable that this field will witness considerable advances in the near future.

In this short essay, I will mainly outline the historical development of Peirce's third semiotic discipline and consider the question of its scope, concluding the overview with a few thoughts on the prospects of rhetorical semiotic. Obviously, my treatment of the issues at hand is severely abridged; I could hardly even begin to fill the many gaps of Peircean rhetoric in this paper. However, I hope my presentation gives some indications of the great potential I see in this line of inquiry.

\section{Rhetoric as a branch of semiotic}

As so many questions regarding Peirce's semiotic project, his division of semiotic into three branches involves many complex questions. Here, matters can be simplified by focusing on two different conceptions of the field of the philosophical study of signs, connected with his early and late semiotic phases.

The first recorded appearance of the term "semiotic" in Peirce's writings (in his 1865 Harvard lectures on the logic of science) merely states that logic is a species of "symbolistic", which in its turn is a branch of "semiotic", the general science of representations. For the young Peirce, logic is not a synonym for the doctrine of signs, but rather the branch of the semiotic of symbols that examines the relations of symbolic representations to their objects (W 1:303 [1865]). He does not pay much attention to the other parts of semiotic. We are told that there is a science of copies and a science of signs, ${ }^{3}$ which accompany the science of symbols, and that symbolistic is divided into grammar, rhetoric, and logic (see Fig. 1); but only the logical part of semiotic is described in any detail.

\footnotetext{
${ }^{2}$ In particular in LISZKA J. J. (1996, 2000) and SANTAELLA BRAGA L. (1999). See also BERGMAN, M. (2000, 2004) for discussions of various aspects of Peirce's rhetoric.

${ }^{3}$ By "signs", Peirce in this context means the kind of representations later named "indices". "Copy" is an early name for "icon".
} 


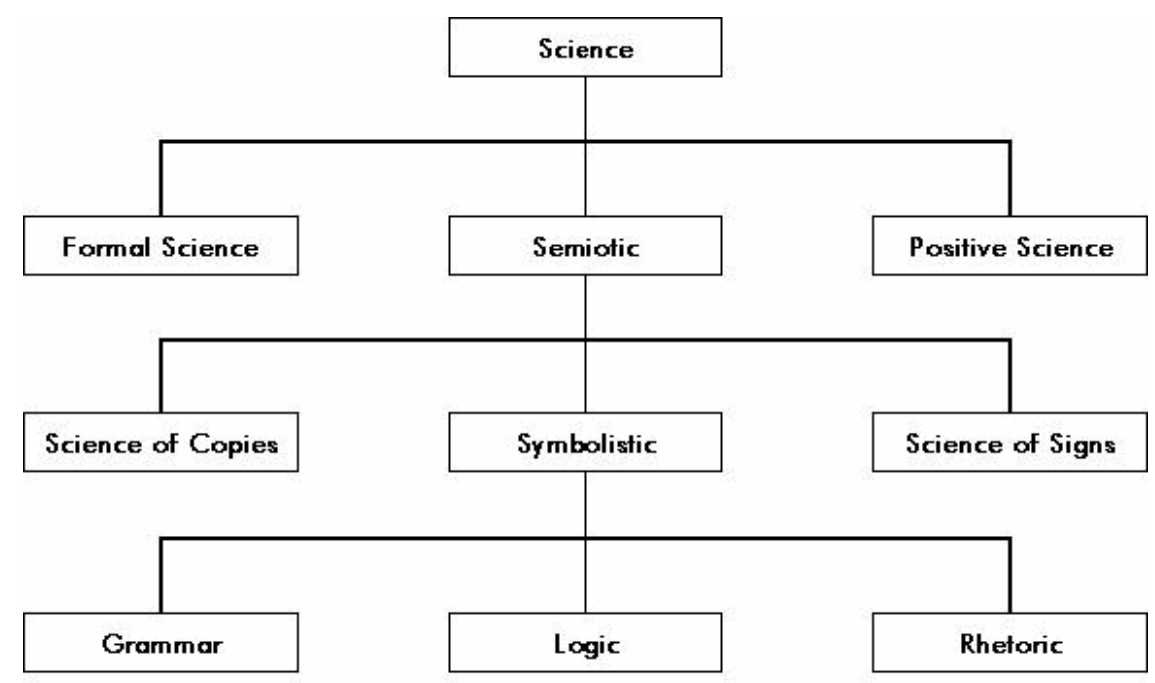

Figure 1. Peirce's classification of the sciences in "Teleological Logic" (1865).

Peirce's characterisation of the science of representations in his youthful writings is rather meagre; it is not possible to form any detailed conception of its scope and content. Nonetheless, some general features of the proposed domain of inquiry may be discerned. In the first place, Peirce's early attention to the science of semiotic follows from an endeavour to find a definition of logic that would avoid the pitfalls of psychologism (see W 1:308 [1865]). Thus, it is evident that the representations, which the various branches of semiotic study, are not to be explicated by an examination of the actual workings of the human mind. Secondly, it is of some interest to note that semiotic is one member of the basic trivium of science, of which the other components are the science of forms (formal science) and the science of things (positive science). This primary trivium can be connected to his work on the theory of categories. In "An Unpsychological View of Logic" (W 1:307-308 [1865]; W 1:313-314 [1865]), Peirce claims that form and matter can be abstracted from the phenomenon considered as an image or a representation. All three phenomenal aspects or elements may be generalised, giving three supposable objects: representations in general, things, and qualities. Positive science studies material things, while formal science examines qualitative forms (W 1:303 [1865]). ${ }^{4}$ Semiotic, as the science of representations, would naturally be concerned with objects of the first kind, that is, with internal and external representations. Using later terminology, we could say that its proper domain is objects as thirds.

The anti-psychologistic emphasis and the intimate connection between the theory of signs and the category of thirdness are pervasive features of Peirce's semiotic, early and late alike. In addition, the trivium of grammar, logic, and rhetoric can also be found in his mature sign-theoretical writings. However, one of the interesting

\footnotetext{
${ }^{4}$ In this trivium of sciences, we may detect an early anticipation of Peirce's later division of sciences into mathematics, philosophy, and special science. On the other hand, it may be wise not to read too much into his earliest attempts to classify the sciences. In particular, Peirce vacillates concerning the relationship between the sciences of representation and form; whereas formal science is clearly (albeit programmatically) distinguished from the science of representations in "Teleological Logic", logic is described as the science of the forms of thought, concerned with both internal and external representations, in "An Unpsychological View of Logic" (1865). Nor is it clear to what extent formal science and semeiotic would be dependent on each other; on the one hand, form and thing are prescinded from representations, but on the other hand, Peirce's diagram of the relationship between the three basic sciences does not suggest any relation of dependency between the disciplines (see $\mathrm{W}$ 1:303-304 [1865]).
} 
features of Peirce's first efforts to characterise semiotic inquiry is that they indicate that he was not originally all that interested in the study of all kinds of signs; rather, what he was looking for in his earliest classification of semiotic was a way to delimit the domain of logic, or the study of how symbols can stand truthfully for their objects. This is not surprising; after all, Peirce was primarily a logician.

Nevertheless, Peirce does offer some attempts to characterise the tasks of the different branches of symbolistic in his early writings. In "Teleological Logic", he asserts that the "science of the general conditions to which every symbol is subjected in so far as it is related to a logos is General Grammar, to a language is General Rhetoric, to an Object is General Logic" (W 1:304 [1865]). In another passage from the same period, Peirce describes the task of rhetoric as that of investigating the laws of a symbol translating anything (W 1:274 [1865]). Or to put the matter in slightly different terms, rhetoric is primarily interested in the laws determining the production of interpretants, representations that in some sense translate the original representation. From a different perspective, rhetoric can be viewed as the science of the intelligibility of symbols (W 1:175 [1865]).

Now, when one turns to Peirce's later writings, at least one major change in his conception of the semiotic sciences that affects the scope of rhetoric may be discerned. The in-between level consisting of the science of copies, the science of signs, and symbolistic is removed. In his mature semiotic, Peirce actually divides logic into the three sub-disciplines or branches of grammar, critic, and rhetoric or methodeutic.

This is related to the relatively well-known fact that Peirce changes his mind about the relationship between semiotic and logic as his thought develops. Whereas the young Peirce strives to carve a place for logic within the part of semiotic he calls symbolistic, the older Peirce conceives of logic as semiotic; and this is to include grammar and rhetoric as well as logic in the narrow sense, or critic as Peirce most often calls the second branch of semiotic.

The term "logic" is unscientifically by me employed in two distinct senses. In its narrower sense, it is the science of the necessary conditions of the attainment of truth. In its broader sense, it is the science of the necessary laws of thought, or, still better (thought always taking place by means of signs), it is general semeiotic. (CP 1.444 [c. 1896])

Peirce now argues that as long as every logical relation is a semiotic relation (which he naturally holds it to be), then the deeper comprehension of logic requires an understanding of all forms of signs and their functions. Consequently, he urges logicians to widen the scope of their research; like medical men examining yeasty diseases study all kinds of yeast, so logicians ought to investigate anything that bears any real analogy to reasoning, and analyse the agreements and disagreements of such occurrences with reasoning (MS 634:15-16 [1909]). Peirce even asserts that the broader investigation is part of the duties of the logician (MS 640:10 [1909]). 


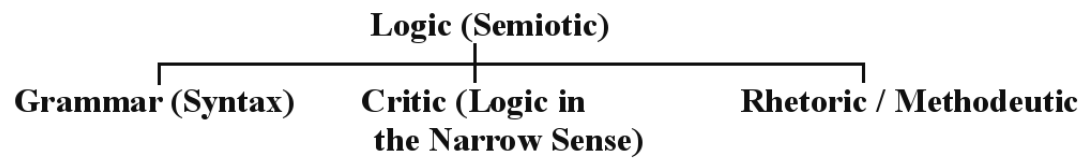

Figure 2. Peirce's Division of Logic in His Later Philosophy

It is clear that Peirce's mature conception of logic as semiotic entails that grammar, critic, and rhetoric are not to be restricted to the study of symbols - that is, to habitual or conventional signs. However, the transformation may have more profound consequences. Arguably, this change in Peirce's approach to logic is not a merely a minor justification in his classification of the sciences; rather, it indicates a growing understanding of the interconnection between the different semiotic subdisciplines. Moreover, whereas Peirce's early forays were primarily motivated by the need to establish the proper framework for logic in the narrow sense, his later work in semiotic in fact ranges over all of the three main semiotic compartments - a fact that may still not be adequately appreciated. In fact, most of what has become known as Peirce's "semiotics" after his death actually belongs to grammar, the first semiotic discipline. If we take Peirce's revised conception of the connection between semiotic and logic seriously, this is simply too narrow a perspective.

\section{Rhetoric versus methodeutic}

As noted at the beginning, Peirce's work on rhetorical matters is altogether rather fragmentary, and it is an open question of what should belong to this area of inquiry. Moreover, the problem of how we should understand the domain of the third branch is heightened by the fact that Peirce appears to waver between a broader and a narrower conception of its domain.

In his later writings, Peirce defines rhetoric as "the study of the necessary conditions of the transmission of meaning by signs from mind to mind, and from one state of mind to another" (CP 1.444 [c. 1896]; cf. NEM 4:331 [1898]). The task of rhetoric "is to ascertain the laws by which in every scientific intelligence one sign gives birth to another, and especially one thought brings forth another" (CP 2.229 [c. 1897]). As such, the emphasis of rhetoric would naturally be on interpretation and other semiotic effects. This conception does not seem to differ greatly from that presented in Peirce's early writings, apart from the rather significant divergence in scope noted above.

However, approximately in 1902, the focus of the third sub-discipline of semiotic begins to turn toward methodological matters, something that is reflected in Peirce's new preferred name, "methodeutic" (see CP 4.9 [1906]). The occurrence of this shift can be seen quite concretely in Minute Logic, where the two terms still co-exist, albeit somewhat uneasily. ${ }^{5}$ The definition of rhetoric offered in this context states that it is substantially the same as methodeutic, and that it is concerned with the "the general conditions of the reference of Symbols and other Signs to the Interpretants which they aim to determine" (CP 2.93 [c. 1902]).

At first, it does not seem that all that much has changed, apart from the name. In his Carnegie Application, Peirce says that "methodeutic looks to the purposed ultimate interpretant and inquires what conditions a sign must conform to, in order

\footnotetext{
${ }^{5}$ In one variant of the text, Peirce explicitly states that he prefers "Speculative Rhetoric" over "Methodeutic" or "Methodology" (MS 425:118); but in other drafts, "methodeutic" is used.
} 
to be pertinent to the purpose" (NEM 4:62 [1902]). However, a year later we find him defining the third sub-discipline as "the principles of the production of valuable courses of research and exposition" (EP 2:272 [1903]). In another characterisation in A Syllabus of Certain Topics of Logic, Peirce says that methodeutic "studies the methods that ought to be pursued in the investigation, in the exposition, and in the application of truth" (EP 2:260 [1903]). More in the same vein follows. The third department of logic "considers how inquiries are to be ordered and arranged" (MS 452:6 [1903]); its "purpose is to ascertain the proper order of procedure in any inquiry" (MS 640:6 [1909]). In short, methodeutic "shows how to conduct an inquiry" (NEM 3:207 [1911]).

Thus, it would appear that Peirce has replaced rhetoric with the more concrete or better-defined methodeutic, at the same time restricting its scope to the study of effective methods. Some scholars have drawn this very conclusion; for instance, according to Santaella Braga, the third branch of semiotic develops from a narrow to a broad sense. ${ }^{6}$ However, at roughly the same time as this transformation takes place, Peirce also continues to write on rhetoric, and even proposes a quite intricate scheme of various rhetorical studies in "Ideas, Stray or Stolen, about Scientific Writing" (1904). ${ }^{7}$ In this context, Peirce defines the third branch of semiotic as "the science of the essential conditions under which a sign may determine an interpretant sign of itself and of whatever it signifies, or may, as a sign, bring about a physical result" (EP 2:326 [1904]; cf. MS 836). However, not all rhetorical questions are necessarily pursued in philosophy. According to Peirce, there is, as a matter of fact, a universal art of rhetoric, which is concerned with "the general secret of rendering signs effective" (EP 2:326 [1904]). From this art, which ought to include such practical concerns as the teaching of eloquence and the improvement of organisational communications, one may abstract the science of rhetoric, which should investigate the principles of everything that the art covers or could cover. It is by no means clear how this characterisation fits with the methodeutic point of view - or even if it is meant to do so.

Now one could obviously argue that "Ideas, Stray or Stolen" is explicitly focused on scientific writing and is therefore naturally a part of methodeutic; it is concerned with the publication of scientific findings, which is a central aspect of the sociality of science according to Peirce. This is true as far as it goes, but it does not explain the discrepancies between the rhetorical and methodeutic perspectives. In fact, it would seem that many of Peirce's characterisations of methodeutic are far narrower than his comparable definitions of rhetoric; some of the methodeutic definitions appear to turn the third branch of semiotic into a set of rules for conducting successful research. Furthermore, in "Ideas, Stray or Stolen" Peirce suggests that rhetoric could be divided into the rhetoric of art, the rhetoric of persuasion, and the rhetoric of science (see EP 2:329 [1904]). This, in turn, could be interpreted to imply that methodeutic is only the part of rhetoric known as rhetoric of science.

Yet, it may be that the contrast between rhetoric and methodeutic should not be exaggerated. By re-conceptualising the third branch of semiotic as methodeutic, Peirce finds a concrete function for it in inquiry. On the other hand, he also wants to retain the broader conception, in which rhetoric is defined in terms of bringing

\footnotetext{
${ }^{6}$ SANTELLA BRAGA L. (1999), p. 380).

${ }^{7}$ Curiously, Santaella Braga claims that it is this very text that signals Peirce's turn from rhetoric to methodeutic (see SANTAELLA BRAGA L. [1999], p. 391).
} 
forth interpretative effects or results. Joseph Ransdell enumerates three principal functions of the third semiotic discipline; it "can be conceived variously as the general methodology of inquiry, as a theory about how beliefs are established when truth is sought, or as a theory about the representational process considered as an autonomous interpretant-generating process". ${ }^{8}$ The autonomy claim is somewhat controversial, but if we speak more broadly about a theory of interpretant generation and communication, then Ransdell's summary should be acceptable to all parties.

These various aspects of rhetoric/methodeutic seem to be reconciled in the following characterisation of the logical trivium:

The whole discussion of the logical nature of the different kinds of possible signs makes up the first division of logic, or Speculative Grammar. The second division, Critic, discusses the relation of signs to their objects, that is, their truth. The third division, Methodeutic, discusses the relations of signs to their interpretants, that is, their knowledge-producing value. (MS 793:20 [c. 1906])

Even more generally, it may be suggested that the third branch of semiotic is concerned with semiotic effects. This would allow for a division of labour between rhetoric and methodeutic; explicitly rhetorical studies would be primarily concerned with communication, while methodeutic investigation would be roughly equivalent to what is usually known as methodology. This proposal seems plausible from the point of view of Peirce's semiotic project. Taking "rhetoric" as an umbrella term, Liszka argues that rhetoric as speculative rhetoric (i.e., as an account of the conditions of communication and the fixation of belief) and rhetoric as methodeutic (i.e., as a systematic procedure for inquiry and for the systematisation of the sciences) are reconcilable within scientific rhetoric, which "works to underscore the formal conditions of inquiry as a practice, including its presuppositions, purposes, principles, and procedures". 9 Apart from certain doubts that could be entertained concerning the aptness of the term "formal conditions" in this context, ${ }^{10}$ Liszka's proposal offers a good summary of the scope of Peirce's rhetoric. It retains the notion that the study of communication is an integral part of semiotic, while at the same time paying due heed to the scientific setting of Peirce's project.

\section{Toward a new pragmatics?}

While there would be much more to say about the details of Peirce's different characterisations of rhetorical inquiry, and of the somewhat troubled relationship between rhetoric and methodeutic, we may now conclude this short sketch of the liveliest branch of semiotic with a few reflections on its import and potential. These may be roughly divided into two parts: the relevance of the rhetorical viewpoint for Peirce's system and the wider significance of Peircean rhetoric.

In the first instance, it is useful to repeat that Peirce's conception of rhetoric both remains the same in certain key respects and changes significantly over time. At

\footnotetext{
${ }^{8}$ RANSDELL J. (1997), §19.

${ }^{9}$ LISZKA J. J. (2000), p. 470.

${ }^{10}$ Admittedly, Peirce sometimes describes the third logical science in such terms, but it might be more appropriate to use "theoretical" or even "speculative" rather than "formal" to avoid confusions. Moreover, it is advisable not to read "conditions" in a strong transcendental sense. Although it seems plausible to think that Peirce's characterisation points in the direction of "transcendental semiotics" (along the lines of APEL K.-O. [1998]), it might be too limiting a frame for a theory that supposedly needs to examine the practical settings of inquiry closely.
} 
least, both early and late he argues that rhetoric, as a part of philosophical semiotic, ought not to be built on psychology. However, whereas Peirce in his early writings shows little interest in the study of rhetoric, his revised conception of the domain of semiotic amounts to a call for expansion of the field of logic. Arguably, the most significant advances occur precisely within the domain of rhetoric - something which to some extent affects the study of semiotic as whole, and may even have repercussions for the Peircean approach to philosophy.

Notably, Peirce moves toward a clearer appreciation of the social and dynamic character of basic semiotic experience - the stuff from which such theoretical entities as sign, object, and interpretant are to be abstracted. In a passage that is not easily reconciled with the formalistic and hierarchical mode of presentation he too often favours in his semiotic, Peirce contends that philosophers "must not begin by talking of pure ideas, - vagabond thoughts that tramp the public roads without any human habituation, - but must begin with men and their conversation" (CP 8.112 [c. 1900]). Ordinary dialogue is singled out as "a wonderfully perfect kind of sign-functioning" (EP 2:391 [c. 1906]). Furthermore, Peirce indicates that semeiotic grammar needs to employ so-called rhetorical evidence, that is, inferences drawn from our commonplace experiences of assertions. This evidential base is formally imperfect. Yet, it does not only provide the initial material for the inquiry, but also constitutes the testing ground for the systematically developed analysis; "the deductions, or quasi-predictions, from the theory having been made, it is requisite to turn to the rhetorical evidence and see whether or not they are verified by observation" (CP 2.333 [c. 1895]).

Another indication of Peirce's escalating interest in rhetoric is the development of his theory of the varieties of interpretants. As has been suggested several times already, rhetoric is the part of semiotic that focuses on semiotic effects, and thus on the interpretant pole of the sign relation. Whereas Peirce's early conception of the interpretant can be roughly summarised as a sign that translates the original sign, his later theory recognises a multiplicity of semiotic effects: for instance emotional, dynamical, and logical interpretants. Also, it is not a coincidence that Peirce in his final years at last succeeds in establishing an explicit connection between semiotic and pragmatism, as he argues that the ultimate logical interpretant is best characterised as a habit of action, or a modification of one (CP 5.476 [1907]). This marriage between pragmatism and semiotic, which is accompanied by fallibilism and critical common-sensism, forms the keystone of the mature rhetorical outlook. Arguably, this point of view paves the way for a richer conception of semiotic, within which questions of communicative context, vagueness, and purpose may be addressed.

Obviously, these rather bold claims would need to be substantiated, but that is a task for more scrupulous study than this somewhat programmatic overview. Instead, I will conclude this essay by suggesting a couple of reasons for giving Peirce's rhetoric a chance to prove its worth.

Firstly, I think a revitalised Peircean rhetoric could give us a new approach to pragmatics. The most well-known attempt to divide semiotic is of course Charles Morris's division of it into syntax, semantics, and pragmatics ${ }^{11}-\mathrm{a}$ three-fold division that was at least to some extent influenced by Peirce's work. Now, although

${ }^{11}$ MORRIS C. (1938). 
Morris and Rudolf Carnap ${ }^{12}$ portrayed syntax, semantics, and pragmatics as the three principal semiotic disciplines, philosophers of language and linguists have tended to ignore this origin, and conceive of syntax, semantics, and pragmatics as three aspects of the study of language. In contrast, Peircean semiotic is of course not restricted to linguistic signs, and this is also true of its rhetorical part. Although the study of language use is certainly among the most important parts of rhetoric, Peirce explicitly proposes a generalisation of rhetoric, so that it would not be restricted to speech (as the traditional conception of rhetoric would have it). Peircean rhetoric would be concerned with the interpretant-generating force of signs of all kinds: algebraic symbols, diagrams, paintings, sculptures, and so on - potentially even of signs without human originators.

At first blush, this does not seem to diverge all that much from Morris's conception of pragmatics, which is the part of semiotic that studies the "relation of signs to interpreters". But there is a crucial difference, in that Peircean rhetoric does not necessarily involve any reference to human subjects. As noted, one of the enduring marks of Peircean semiotic is its anti-psychologistic stance - albeit Peirce concedes that it may be acceptable to loosen the demands a bit when we come to rhetoric, and even accepts that some psychological facts may need to be taken into account (see CP 2.107 [c. 1902]). Still, I think that the main upshot of a Peircean approach to pragmatics would be a broadening of its scope - or perhaps rather a change of perspective from that of treating sign use psychologically to that of focusing on the effects of various kinds of signs.

Possibly, semiotics could more generally benefit from an appropriately revised Peircean way of dividing its field. This may go against the flow of much current work in semiotics, for which a division into grammar, critic, and rhetoric appear to be unnecessarily stiff and scholarly. However, there is at least this to be said for the Peircean point of view: it could serve as an aid in attempts to organise our semiotic efforts. Perhaps controversially, I would like to suggest that the rather formless field of present-day semiotics could use some methodical reordering; and while Peirce of course does not give us all the answers, his notion of semiotic inquiry is worthy of some consideration even in this day and age. Suitably applied, it could lead us toward a conception of semiotics capable of sustaining productive interaction between practical semiotic rhetoric and philosophical semiotic grammar, with theoretical rhetoric occupying a mediating position.

On the other hand, it is clear that much work remains to be done. Peircean semiotic is sometimes presented as a truly general perspective, capable of encompassing the entire field of semiotic studies. Lacking an adequately developed rhetoric capable of connecting theory with practice, this will remain a rather empty boast. At any rate, I feel that the pursuit of rhetoric is the path that Peircean semiotic must follow in order to begin to fulfil its potential, and to emerge as a genuinely viable framework for the study of the varieties of semiosis.

\section{References}

APEL K.-O., 1998 - From a Transcendental-Semiotic Point of View, Manchester, Manchester University Press.

\footnotetext{
${ }^{12}$ CARNAP R. (1946).
} 
BERGMAN M., 2000 - "Reflections on the Role of the Communicative Sign in Semeiotic", Transactions of the Charles S. Peirce Society, XXXVI(2), 225254.

BERGMAN M., 2004 - Fields of Signification: Explorations in Charles S. Peirce's Theory of Signs, Vantaa, Philosophical Studies from the University of Helsinki 6.

CARNAP R., 1946 - Introduction to Semantics, Cambridge, MA, Harvard University Press.

LISZKA, J. J., 1996 - A General Introduction to the Semeiotic of Charles Sanders Peirce, Bloomington, Indiana University Press.

LISZKA J. J., 2000 - "Peirce's New Rhetoric", Transactions of the Charles $S$. Peirce Society, XXXVI (4), 439-476.

MORRIS C. W., 1938 - Foundations of Semiotic, Chicago, The University of Chicago Press.

PEIRCE C. S., 1931-58 - Collected papers of Charles S. Peirce. 8 vols. Ed. by C. Hartshorne \& P. Weiss (vols. 1-6), \& A. Burks (vols. 7-8). Cambridge, MA, Harvard University Press.

PEIRCE C. S., 1976 - The New Elements of Mathematics. 4 vols. Ed. by C. Eisele. The Hague, Mouton Publishers.

PEIRCE C. S., 1977 - Semiotic and Significs: The Correspondence between Charles S. Peirce and Victoria Lady Welby. Ed. by C. S. Hardwick. Bloomington, Indiana University Press.

PEIRCE C. S., 1982- - Writings of Charles S. Peirce: A Chronological Edition. 6 vols. to date. Ed. by The Peirce Edition Project. Bloomington: Indiana University Press.

PEIRCE C. S., 1992-8). The Essential Peirce: Selected Philosophical Writings. 2 vols. Ed. by N. Houser \& C. Kloesel (vol. 1), \& The Peirce Edition Project (vol. 2). Bloomington, Indiana University Press.

RANSDELL J., 1997 - "Is Peirce a Phenomenologist?", Retrieved October 30, 2001, from ARISBE, http://members.door.net/arisbe/menu/library/aboutcsp/ransdell/phenom.htm. (Article originally published in 1989 in Études Phénoménologiques 9-10, pp. 51-75, trans. into French by A. De Tienne)

SANTAELLA BRAGA L., 1999 - "Methodeutics, the Liveliest Branch of Semiotics", Semiotica, 124 (3/4), 377-395. 